\title{
THE VARIATION IN WATER CONTENT AND IN CONCENTRATIONS IN TRACE METALS IN PEAT IN DIFFERENT MIRE TYPES
}

\author{
YAN HE and KIMMO VIRTANEN
}

\begin{abstract}
HE, YAN and VIRTANEN, KIMMO 1991. The variation in water content and in concentrations in trace metals in peat in different mire types. Bull. Geol. Soc. Finland 63, Part 2, 121-128.

The mires in Ostrobothnia, Western Finland, can be classified into four types by trophic status: oligotrophic, oligo-mesotrophic, mesotrophic and meso-eutrophic mires. Geological investigations and analyses show that there are differences in the water content and in the concentrations of trace metals of peat between these mire types. The water content of peat is highest in oligotrophic mires, the average being $91.3 \%$, and lowest in meso-eutrophic mires, where it is $86.4 \%$. The water content of peat gradually decreases with an increase in the proportion of moss peat and in the degree of decomposition of peat from oligotrophic mires through oligomesotrophic and mesotrophic mires to meso-eutrophic mires. In all the mire types, $\mathrm{Zn}, \mathrm{Pb}$ and $\mathrm{Cd}$ values are relatively high in peat, whereas $\mathrm{Ni}, \mathrm{Cr}, \mathrm{Cu}, \mathrm{Co}$ and $\mathrm{Mn}$ show rather low concentrations in the uppermost peat layer. The concentrations of trace metals ( $\mathrm{Cr}, \mathrm{Mn}, \mathrm{Pb}$ and $\mathrm{Fe}$ ) in peat are highest in meso-eutrophic mires, but the concentrations of $\mathrm{Co}$ and $\mathrm{Cu}$ are highest in mesotrophic mires. The values of $\mathrm{Zn}$ are highest in oligotrophic mires and of $\mathrm{Ni}$ in oligo-mesotrophic mires. The concentrations of $\mathrm{Cr}, \mathrm{Cd}, \mathrm{Mn}, \mathrm{Fe}$ and $\mathrm{Pb}$ gradually increase and those of $\mathrm{Zn}$ gradually decrease from oligotrophic mires through oligo-mesotrophic and mesotrophic mires to meso-eutrophic mires.
\end{abstract}

Key words: bogs, peat, water content, heavy metals, Oulu County, Finland.

Yan He: Changchun Institute of Geography, Academia Sinica. 130021 Changchun, P.R. of China.

Kimmo Virtanen: Geological Survey of Finland. SF-70701 Kuopio, Finland.

\section{Introduction}

Peat is a heterogeneous mixture of organic matter accumulated in a water-saturated environment. Previously, the differences in water content and in concentrations of trace metals at different peat depths were emphasized (Salmi 1955, Largin et al. 1972, Sillanpää 1972, Tanskanen 1976, Yliruokanen 1976, 1980, 1981, Pakarinen et al. 1977, 1978b, 1980, 1983, Glooschenko \& Capobianco 1978, Peuravuori et al. 1988 and Virtanen 1990, 1991). However, little attention was paid to the variation in water content and in concentrations of trace metals in peat in different mire types. The purpose of this paper is to compare different mire types in terms of water content and the concentration of trace metals.

\section{Study material}

The study area, which lies in Ostrobothnia, Western Finland, comprises three regions in the municipalities of Ruukki, Vihanti and Oulainen 


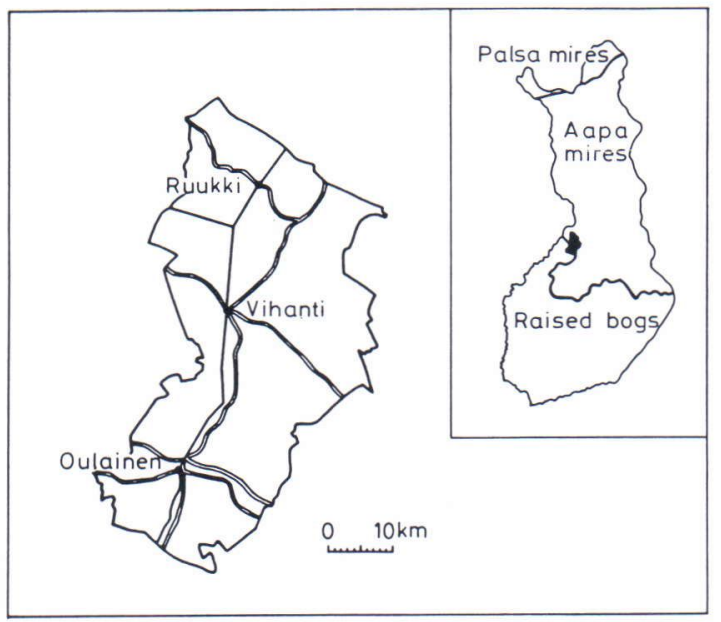

Fig. 1. The location of studied region.

(Fig. 1). Altogether 240 mires, with a total surface area of 50,000 hectares, have been investigated (Virtanen \& Herranen 1984, 1986, 1987, 1988). The findings presented in this paper are based on the material investigated earlier. The degree of decomposition and the botanical characteristics of the peat and mire types were determined in the field (Lappalainen et al. 1984). The water content (DIN 19683) and the bulk density were measured with method by Korpijaakko (1981), and the concentrations of trace metals $(\mathrm{Co}, \mathrm{Cr}, \mathrm{Cu}, \mathrm{Mn}$, $\mathrm{Ni}, \mathrm{Pb}, \mathrm{Zn}, \mathrm{Cd}$ and $\mathrm{Fe}$ )in peat were determined from peat ash by AAS (combustion temperature $450^{\circ} \mathrm{C}$ ) and then calculated to dry peat in the laboratory.

\section{Results}

\section{Mire and peat types}

The mires of the study area can be classified by trophic status (Cajander 1913, Heikurainen \& Pakarinen 1982, Ruuhijärvi 1983, Lappalainen et al. 1984) into the following types:
(1) oligotrophic mires;
(2) oligo-mesotrophic mires;
(3) mesotrophic mires;
(4) meso-eutrophic mires.

According to geological investigations (Virtanen and Herranen 1984, 1986, 1987, 1988) there are two main peat types in this region, i.e. Carex peat and Sphagnum peat. An average of $58 \%$ of the peat deposits are composed of Carex peat and $42 \%$ of Sphagnum peat. However the proportion of peat types differs from one mire type to another (Table 1).

Table 1. Statistical parameters of water content of peat in four types of mire.

\begin{tabular}{|c|c|c|c|c|c|c|c|c|}
\hline \multirow[t]{2}{*}{ Mire types } & \multicolumn{2}{|c|}{ Peat types } & \multirow[t]{2}{*}{ mean $(\%)$} & \multirow[t]{2}{*}{ Std. } & \multirow[t]{2}{*}{$\mathrm{Cv}$} & \multirow[t]{2}{*}{$\operatorname{Mmax}(\%)$} & \multirow[t]{2}{*}{$\operatorname{Mmin}(\%)$} & \multirow[t]{2}{*}{$\mathrm{N}$} \\
\hline & $\mathrm{S} \%$ & C \% & & & & & & \\
\hline $\begin{array}{l}\text { oligotrophic } \\
\text { mire }\end{array}$ & 83 & 17 & 91.30 & 3.77 & 0.041 & 96.50 & 80.60 & 98 \\
\hline $\begin{array}{l}\text { oligo-meso- } \\
\text { trophic mire }\end{array}$ & 76 & 24 & 89.40 & 4.18 & 0.047 & 95.50 & 80.50 & 46 \\
\hline $\begin{array}{l}\text { mesotrophic } \\
\text { mire }\end{array}$ & 30 & 70 & 87.90 & 3.38 & 0.038 & 93.90 & 83.40 & 16 \\
\hline $\begin{array}{l}\text { meso-eutro- } \\
\text { phic mire }\end{array}$ & 26 & 74 & 86.40 & 3.58 & 0.04 & 93.60 & 80.90 & 10 \\
\hline
\end{tabular}

Std.: Standard deviation; $\mathrm{Cv}$ : Coefficient of variation;

Mmax: Maxiumum value; Mmin: Minimum value;

$\mathrm{N}$ : Number of sample.

S: Sphagnum

C: $\quad$ Carex 


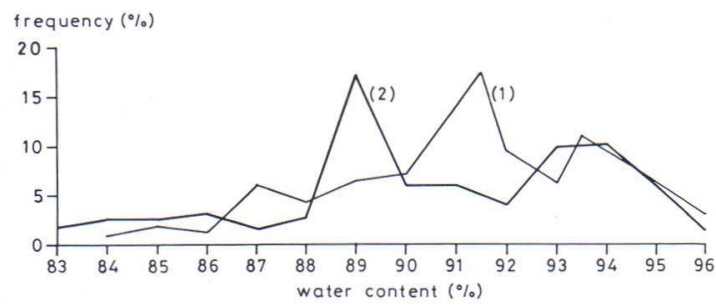

(1) oligotrophic mire (2) oligo-mesotrophic mire

Fig. 2. The frequency of water content of peat in oligotrophic mire and oligo-mesotrophic mire.

\section{Water content}

The water content in peat differs in the four mire types as shown in Table 1. The content is highest in oligotrophic mires, where it is $91.3 \%$ on average, and the coefficient of variation is only 0.041 . It is lowest in meso-eutrophic mires, where it is $86.4 \%$ on average, and the coefficient of variation is 0.04 . The mean values of the water content in peat in the four types of mire are in declining order:

oligotrophic mires > oligo-mesotrophic mires $>$ mesotrophic mires $>$ meso-eutrophic mires.

Figures 2 and 3 indicate that the water content in the peat of oligotrophic mires is usually in the range $89 \%-93 \%$, the frequency in this range being $46.9 \%$. In oligo-mesotrophic mires the content is from $88 \%$ to $91 \%$, the frequency being $31.8 \%$. In mesotrophic mires which make up $43.8 \%$ of the samples determined, the water content is in the range $86 \%-90 \%$. The mode interval in meso-trophic mires, however, is $84 \%$ $88 \%$, the freguency in this range being $73 \%$.

The observed diversity depends principally on the types of dead plant remains and the degree of decomposition. It is also related to bulk density and microbiological activity. The leaforganism of moss peat is composed of transparent dead cells which can hold water. The water content is therefore highest in moss peat. Generally, the water content decreases as the degree of decomposition increases (Radforth \& Brawner 1977).

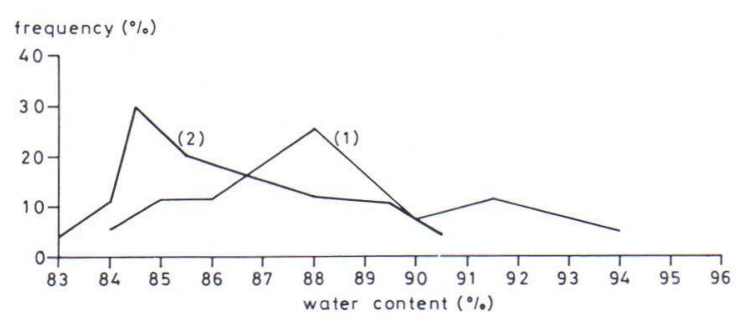

(1) mesotrophic mire (2) meso-eutrophic mire

Fig. 3. The frequency of water content of peat in mesotrophic mire and meso-eutrophic mire.

However, in highly decomposed peat, even though the amount of water retained at low suction decreases as decomposition increases, at higher suction more water is retained.

Remains of Sphagnum play a very important role in oligotrophic mires. The proportions of Sphagnum peat gradually decrease, from $83 \%$ to $26 \%$, from oligotrophic mires through oligomesotrophic mires and mesotrophic mires to meso-eutrophic mires. The degree of humification of peat in oligo-trophic mires is higher than that in meso-eutrophic mires. Another reason why the water content of peat decreases with the change in mire type from oligotrophic through oligo-mesotrophic and mesotrophic mires to meso-eutrophic mires is that all the meso-eutrophic mires in the study area have been drained.

\section{Concentrations of trace metals}

The mean concentrations of the trace metals analysed in the different mire types are shown in Table 2. The different forms of expression of the analytical results are given in Table 3. Comparison of Table 2 with Table 3, reveals slight variations due to differences in the bulk density of peat in the four mire types.

The enrichment of elements in to the uppermost peat layer was evaluated by calculating the concentration ratios »uppermost peat/whole peat» (Table 4).

On the basis of Table 4, the following rankings were obtained: 
Table 2. Mean concentrations of trace metals of peat in the four mire types.

\begin{tabular}{lccccccccc}
\hline mire types & $\begin{array}{c}\mathrm{Co} \\
(\mathrm{ppm})\end{array}$ & $\begin{array}{c}\mathrm{Cr} \\
(\mathrm{ppm})\end{array}$ & $\begin{array}{c}\mathrm{Cu} \\
(\mathrm{ppm})\end{array}$ & $\begin{array}{c}\mathrm{Mn} \\
(\mathrm{ppm})\end{array}$ & $\begin{array}{c}\mathrm{Ni} \\
(\mathrm{ppm})\end{array}$ & $\begin{array}{c}\mathrm{Pb} \\
(\mathrm{ppm})\end{array}$ & $\begin{array}{c}\mathrm{Zn} \\
(\mathrm{ppm})\end{array}$ & $\begin{array}{c}\mathrm{Cd} \\
(\mathrm{ppm})\end{array}$ & $\begin{array}{c}\mathrm{Fe} \\
(\%)\end{array}$ \\
\hline $\begin{array}{l}\text { oligotrophic } \\
\text { oligo-meso- }\end{array}$ & 0.76 & 6.74 & 3.38 & 51.28 & 1.45 & 10.58 & 29.3 & 0.27 & 0.21 \\
$\begin{array}{l}\text { trophic } \\
\begin{array}{l}\text { mesotrophic } \\
\text { meso-eutro- }\end{array}\end{array}$ & 1.22 & 19.24 & 4.37 & 59.75 & 2.78 & 14.24 & 21.17 & 0.29 & 0.54 \\
phic & 2.25 & 25.73 & 5.47 & 66.20 & 2.45 & 15.37 & 19.67 & 0.50 & 0.73 \\
\hline
\end{tabular}

Table 3. The amount of trace metals as $\mathrm{g} / \mathrm{m}^{3}$ dry peat in the different mire types.

\begin{tabular}{lccccccccc}
\hline mire types & $\mathrm{Co}$ & $\mathrm{Cr}$ & $\mathrm{Cu}$ & $\mathrm{Mn}$ & $\mathrm{Ni}$ & $\mathrm{Pb}$ & $\mathrm{Zn}$ & $\mathrm{Cd}$ & $\mathrm{Fe}$ \\
\hline $\begin{array}{l}\text { oligotrophic } \\
\text { oligo-meso- }\end{array}$ & 0.08 & 0.71 & 0.37 & 5.56 & 0.16 & 1.15 & 3.18 & 0.03 & 227.83 \\
$\begin{array}{l}\text { trophic } \\
\text { mesotrophic }\end{array}$ & 0.15 & 2.32 & 0.53 & 7.19 & 0.34 & 1.71 & 2.55 & 0.04 & 649.89 \\
$\begin{array}{l}\text { meso-eutro- } \\
\text { phic }\end{array}$ & 0.30 & 3.44 & 0.73 & 8.85 & 0.33 & 2.06 & 2.63 & 0.07 & 976.16 \\
\hline
\end{tabular}

(1) oligotrophic mires

$\mathrm{Zn}, \mathrm{Pb}>\mathrm{Cd}>\mathrm{Cu}, \mathrm{Mn}, \mathrm{Co}>\mathrm{Ni}, \mathrm{Cr}, \mathrm{Fe}$

(2) oligo-mesotrophic mires

$\mathrm{Zn}, \mathrm{Pb}>\mathrm{Cd}>\mathrm{Co}, \mathrm{Cr}, \mathrm{Ni} \mathrm{Mn}, \mathrm{Fe}, \mathrm{Cu}$

(3) mesotrophic mires

$\mathrm{Zn}, \mathrm{Pb}, \mathrm{Cd}>\mathrm{Co}, \mathrm{Fe}, \mathrm{Cr}, \mathrm{Cu}>\mathrm{Mn}, \mathrm{Ni}$

(4) meso-eutrophic mires

$\mathrm{Pb}, \mathrm{Zn}, \mathrm{Cd}>\mathrm{Cr}, \mathrm{Co}>\mathrm{Mn}, \mathrm{Cu}, \mathrm{Fe}>\mathrm{Ni}$.

Significant differences can be seen in the levels of the nine trace metals in the four types of mire when compared with the average concentrations of trace metals in peat in the study region (Fig.4).

\section{Discussion}

Table 4 and Figure 4 show the characteristics and the trace metal contents of peat in different mire types.

(1) oligotrophic mires

$\mathrm{Zn}$ and $\mathrm{Pb}$ are enriched, but the contents of $\mathrm{Cu}, \mathrm{Mn}, \mathrm{Co}, \mathrm{Ni}, \mathrm{Cr}$ and $\mathrm{Fe}$ are consistently low- er, in the uppermost peat. Only Cd shows a relatively small change in average value from the uppermost peat layer to the whole peat layer. The mean concentrations of all the elements except $\mathrm{Zn}$, whose concentration is higher than in the other four types of mire, are low; those of $\mathrm{Cr}, \mathrm{Mn}$, $\mathrm{Pb}, \mathrm{Cd}$ and $\mathrm{Fe}$ are especially low, being lower than in the other mire types, and, except for $\mathrm{Zn}$ and $\mathrm{Pb}$, are lower than the mean concentrations of trace metals in the peat of the study region.

(2) oligo-mesotrophic mires

Apart from $\mathrm{Zn}$ and $\mathrm{Pb}$, which appear to be enriched in the uppermost peat, all the elements except $\mathrm{Cd}$ show lower concentrations in the uppermost peat. Only $\mathrm{Cd}$ shows a relatively small change in average value between the uppermost peat layer and the whole peat layer. The mean content of $\mathrm{Ni}$ is the highest reconted in any of the mire types. With the exception of $\mathrm{Zn}$, all other elemental concentrations, are higher than those in oligotrophic mires, and except for $\mathrm{Zn}$, Co and $\mathrm{Cu}$, are lower than those in mesotrophic and meso-eutrophic mires. Only $\mathrm{Zn}$ and $\mathrm{Pb}$ are higher 
The variation in water content and in concentrations in trace metals in peat in different mire types
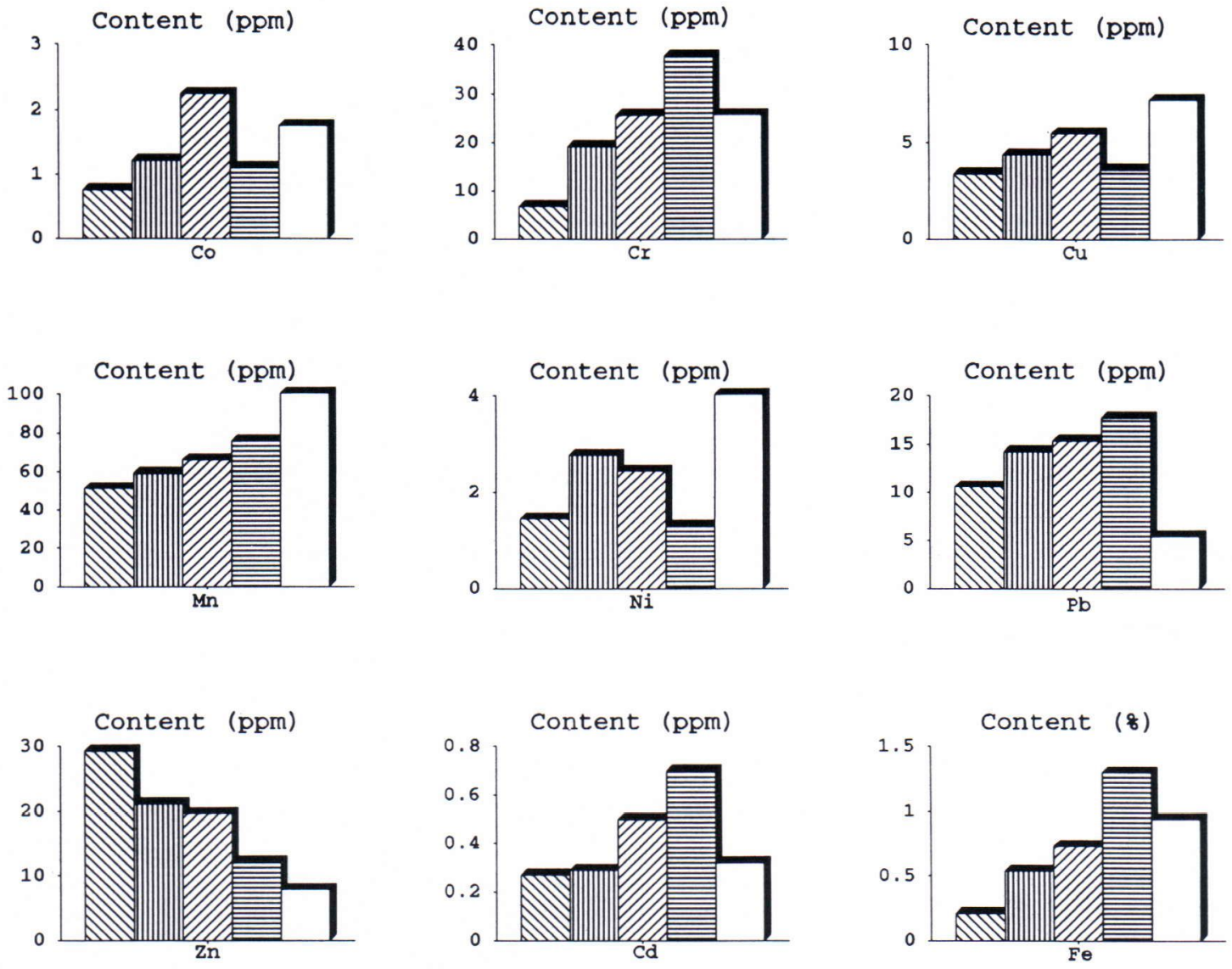

oligotrophic mire

oligo-mesotrophic mire mesotrophic mire meso-eutrophic mire mean value in western Finland

Fig. 4. The concentrations of trace metals of peat in different mire types.

Table 4. The ratios of trace metal concentrations in the uppermost peat layer to those in the whole peat layer.

\begin{tabular}{lccccccccc}
\hline mire types & $\mathrm{Co}$ & $\mathrm{Cr}$ & $\mathrm{Cu}$ & $\mathrm{Mn}$ & $\mathrm{Ni}$ & $\mathrm{Pb}$ & $\mathrm{Zn}$ & $\mathrm{Cd}$ & $\mathrm{Fe}$ \\
\hline $\begin{array}{l}\text { oligotrophic } \\
\text { oligo-meso- }\end{array}$ & 0.52 & 0.38 & 0.60 & 0.58 & 0.43 & 2.20 & 2.90 & 1.13 & 0.33 \\
$\begin{array}{l}\text { trophic } \\
\begin{array}{l}\text { mesotrophic } \\
\text { meso-eutro- }\end{array}\end{array}$ & 0.63 & 0.62 & 0.43 & 0.51 & 0.61 & 2.43 & 2.46 & 1.14 & 0.51 \\
phic & 1.01 & 0.89 & 0.89 & 0.55 & 0.55 & 2.24 & 2.50 & 1.72 & 0.92 \\
\hline
\end{tabular}


than the mean concentrations of trace metals in the peat of the study area.

(3) mesotrophic mires

$\mathrm{Zn}, \mathrm{Pb}$ and $\mathrm{Cd}$ are enriched in the uppermost peat, while $\mathrm{Mn}$ and $\mathrm{Ni}$ show lower concentrations. The $\mathrm{Co}, \mathrm{Fe}, \mathrm{Cr}$ and $\mathrm{Cu}$ of the uppermost peat show relatively small changes in the whole peat layer. The concentrations of $\mathrm{Co}$ and $\mathrm{Cu}$ are the highest observed in any of the mire types. The concentrations of $\mathrm{Co}, \mathrm{Cd}, \mathrm{Zn}$ and $\mathrm{Pb}$ are higher than the averages of all the studied material. The average values of $\mathrm{Cr}, \mathrm{Mn}, \mathrm{Pb}, \mathrm{Cd}$ and $\mathrm{Fe}$ are higher than those in oligotrophic and oligomesotrophic mires and lower than those in mesoeutrophic mires.

(4) meso-eutrophic mires

While $\mathrm{Pb}, \mathrm{Zn}$ and $\mathrm{Cd}$ appear to be markedly enriched in the uppermost peat, Ni exhibits lower concentrations. $\mathrm{Co}$ and $\mathrm{Cr}$ show a relatively small change in average value from the uppermost peat layer to the whole peat layer. The concentrations of $\mathrm{Cr}, \mathrm{Cd}, \mathrm{Fe}, \mathrm{Mn}$ and $\mathrm{Pb}$ are the highest encountered in any of the mire types. The mean values of $\mathrm{Cr}, \mathrm{Pb}, \mathrm{Zn}, \mathrm{Cd}$ and $\mathrm{Fe}$ are higher than those of peat in the study area. Only Ni and $\mathrm{Zn}$ show lower concentrations than in any of other mire types.

These results show some similaritiers with previous data on trace metal concentrations in different peat types. The concentrations of $\mathrm{Zn}$ and $\mathrm{Pb}$ in peat are clearly highest in the uppermost layer whether in different peat types or in different mire types (Salmi 1956, 1959, 1967, Tanskanen 1976, Pakarinen et al. 1977, 1980, Peuravuori \& Pihlaja 1988, Shotyk 1988, Äikäs \& Leino 1990, Sillanpää 1972, Elomaa 1981, Yliruokanen 1976, 1980, Virtanen 1991). On the other hand, the contents of $\mathrm{Ni}, \mathrm{Cr}, \mathrm{Cu}, \mathrm{Co}$ and $\mathrm{Mn}$ in peat are quite low in the uppermost layer of Finnish mires (Salmi 1956, Tanskanen 1976, Sillanpää 1972, Yliruokanen 1976, 1981, Peuravuori \& Pihlaja 1988). The content of $\mathrm{Fe}$ is highest in meso-eutrophic mires, and lowest in oligotrophic mires (Puustjärvi 1952, Tolonen 1974, Salmi 1955, Sillanpää 1972, 1975).

\section{Conclusions}

The following conclusions can be drawn from the variation in water content and in concentrations of trace metals in peat in different mire types:

1. The water content of peat decreases gradually from oligotrophic mires through oligomesotrophic and mesotrophic mires to mesoeutrophic mires, from $91.3 \%$ to $86.4 \%$, on average. In oligotrophic and oligo-mesotrophic mires, the common ranges of the water content of peat are $89 \%-93 \%$ and $88 \%-91 \%$ respectively, and the respective freguencies are $46.9 \%$ and $31.8 \%$. In mesotrophic and meso-eutrophic mires, however, the common ranges are $86 \%-90 \%$ and $84 \%-88 \%$ respectively, and the frequencies $43.8 \%$ and $73 \%$, respectively.

This difference mainly depends on the type and humification degree of peat in different mires.

2 . The average concentrations of the trace metals studied in peat differ in the four mire types. The concentrations of $\mathrm{Cr}, \mathrm{Mn}, \mathrm{Pb}, \mathrm{Cd}$ and $\mathrm{Fe}$ the highest, but those of $\mathrm{Ni}$ and $\mathrm{Zn}$ are lowest, in meso-eutrophic mires. The concentrations of $\mathrm{Zn}$ and $\mathrm{Ni}$ are highest in oligotrophic and oligomesotrophic mires whereas the mean values of $\mathrm{Cr}, \mathrm{Mn}, \mathrm{Pb}, \mathrm{Cd}$ and $\mathrm{Fe}$ are lowest in oligotrophic mires. Although the concentrations of trace metals in peat differ in the four types of mire, they do show some similarities. $\mathrm{Zn}, \mathrm{Pb}$ and $\mathrm{Cd}$ have relatively high concentrations, whereas $\mathrm{Ni}, \mathrm{Cr}, \mathrm{Cu}, \mathrm{Co}$ and $\mathrm{Mn}$ exhibit relatively low concentrations in the uppermost peat layer in all the mire types. More over the concentrations of $\mathrm{Cr}$, $\mathrm{Cd}, \mathrm{Mn}, \mathrm{Fe}$ and $\mathrm{Pb}$ gradually increase from oligotrophic mires through oligo-mesotrophic and mesotrophic mires to meso-eutrophic mires while the content of $\mathrm{Zn}$ gradually decreases.

Acknowledgement. We are most grateful to Dr Eino Lappalainen for reading and greatly improving the manuscript. We also thank Ms. Ritva Jokisaari for making the drawings. 


\section{References}

Cajander, A.K., 1913. Studien über die Moore Finlands. Acta For. Fenn., 2(3), 1-208.

Elomaa, P-L., 1981. Suokasvillisuuden ja turpeen käytöstä malminetsinnässä (with English summary: Use of mire vegetation and peat for mineral exploration). Suo 32 (2): $45-52$.

Glooschenko, W.A. and Capobianco, J.A., 1978. Metal content of Sphagnum mosses from two northern Canadian bog ecosystems. Water, Air and Soil Pollut. 10, 215220.

Heikurainen, L. \& Pakarinen, P., 1982. Mire vegetation and site types. In: Jukka Laine(ed.), Peatlands and their utilization in Finland. Finnish Peatland Society, Finnish National Committee of the International Peat Society, Helsinki, $139 \mathrm{p}$.

Korpijaakko, $M, 1981$. Uusi kairatyyppi tilavuustarkkojen turvenäytteiden ottamiseen (with an English summary: A piston sampler for undisturbed peat samples). Suo 32 (1), $7-8$.

Lappalainen, E., Stén, C-G. and Häikiö, J., 1984. Turvetutkimusten maasto-opas. Geologinen tutkimuslaitos. Opas nor 12. Espoo, 62 p.

Largin, I.F., Priemskaya, S.E., Sventikhovskaya, A.N. and Tyuremnov, S.N., 1972. Microelement content and distribution in peat deposits. Proceedings of the 4th International Peat Congress. Otaniemi, Finland, June 25-30, 1972, p. 77.

Pakarinen, P., 1978b. Distribution of heavy metals in Sphagnum layer of bog hummocks and hollows. Ann. Bot. Fennici 15, 287-292.

—, Gorham, E., 1983. Mineral element composition of Sphagnum fuscum peats collected from Minnesota, Manitoba and Ontario. International Symposium on Peat Utilization. Bemidij, U.S.A., October 10-13, 1983, p. 417.

—, Tolonen, K., 1977. Pääravineteiden sekä sinkin ja lyijyn vertikaalijakautumasta rahkaturpeessa (with English summary: Vertical distributions of $\mathrm{N}, \mathrm{P}, \mathrm{K}, \mathrm{Zn}$ and $\mathrm{Pb}$ in Sphagnum peat). Suo 28 (4-5): 95-102.

-, -, Soveri, J., 1980. Distribution of trace-metals and sulphur in the surface peat of Finnish raised bogs. Proceedings of the 6th International Peat Congress. Duluth, U.S.A., August 17-23, 1980, p. 645.

Peuravuori, J., Pihlaja, K., 1988. Turvesoiden kemiallinen kartoitus energiatuotantoa silmälläpitäen (with English summary: Chemical mapping of peatlands with special emphasis on energy production). KTM, Sarja D:148, Helsinki.

-, -, Heikka, R. and Minkkinen, P., 1988. Inorganic constituents in Finnish peatlands - A correlative approach. Proceedings of the 8 th International Peat Congress. Leningrad, U.S.S.R., 1988, p. 189.
Puustjärvi, V., 1952. The precipitation of iron in peat soils. Suomen Maatal. tiet.seuran julk. 78.1.

Radforth, N.W. \& Brawner, C.O., 1977. Muskeg and the Northern Environment in Canada. University of Toronto Press, Toronto and Buffalo, $399 \mathrm{p}$.

Ruuhijärvi, R., 1983. The Finnish mire types and their regional distribution. In: Gore, T. \& Goodall, D. (eds), Ecosystems of the World 4B, Mires. Elsevier Scientific Publishing Company, Amsterdam, $479 \mathrm{p}$.

Salmi, M., 1955. Prospecting for bog-covered ore by means of peat investigations. Bull. Comm. Geol. Finlande 169, $34 \mathrm{p}$.

- 1956. Peat and bog plants as indicators of ore minerals in Vihanti ore field in Western Finland. Bull. Comm. Geol. Finlande 175. 22 p.

-, 1959. On peat-chemical prospecting in Finland. Cong. Geol. Internac. XX a sec. Mexico 1956, 243-253.

,- 1967. Peat in prospecting: Applications in Finland. In: Kvalheim(ed.), Geochemical prospecting in Fennoscandia, 113-126.

Shotyk, W., 1988. Review of the inorganic geochemistry of peats and peatland waters. Earth-Science Reviews 25, 95-176.

Sillanpää, M., 1972. Distribution of trace elements in peat profiles. Proceedings of the 4th International Peat Congress. Otaniemi, Finland, June 25-30, 1972, p. 185.

Tanskanen, H., 1976. Factors affecting the metal contents in peat profiles. In: L.K. Kauranne (ed.), Jour. geochem. expl. "Prospecting in Fennoscandia», 412-414.

Tolonen K., 1974. On the nutrient content of surface water in ombrotrophic mire complexes in Finland. Suo 25: $41-51$.

Virtanen K., 1991. Effect of bedrock on trace element concentration of fuel peat. Geological Survey of Finland. Special Paper, 9, 241-246.

,- 1990 . The influence of bedrock belts on the trace elements of mires in Haapavesi, Central Finland. PEAT 90 - versatile peat. International Conference on Peat Production and Use. Jyväskylä, Finland, June 11-15, 1990, p. 462.

-, Herranen T., 1984. Vihannissa tutkitut suot ja niiden turvevarat. Osa I. Geological Survey of Finland, Peat report 167.

—, Herranen T., 1986. Vihannissa tutkitut suot ja niiden turvevarat (with English summary). Osa II. Geological Survey of Finland, peat report 188 .

-, Herranen T., 1987. Ruukissa tutkitut suot ja niiden turvevarat. Osa I. Geological Survey of Finland, Peat report 203.

-, Herranen T., 1988. Ruukissa tutkitut suot ja niiden turvevarat (with English summary). Osa II. Geological Survey of Finland, peat report 210 .

—, Herranen T., 1988. Oulaisissa tutkitut suot ja niiden turvevarat (with English summary). Geological Survey of Finland, peat report 218. 
Yliruokanen I., 1981. The occurrence of copper and nickel in some Finnish peat bogs. Kemia - Kemi 4: 229-233.

,- 1980 . The occurrence of zinc in some Finnish peat bogs. Kemia - Kemi 7-8: 447-450.

,- 1976 . Heavy metal distributions and their significance in Finnish peat bogs. Proceedings of the 5th International Peat Congress. Poznan, Poland, September 21-25, 1976, p. 276.
Äikäs O. \& Leino J., 1990. Enrichments of young uranium in peat: Materinsuo and Peurasuo, Finland. PEAT $90-$ versatile peat. International Conference on Peat Production and Use. Jyväskylä, Finland, June 11-15, 1990, p. 493.

Received May 10, 1991

Revision accepted August 27, 1991 